\title{
PENGARUH KOMPONEN HARGA PEMBIAYAAN (COST OF LOANABLE FUND, OVERHEAD COST DAN RISK FACTOR) TERHADAP PRICING PEMBIAYAAN BERBASIS BAGI HASIL DI INDUSTRI PERBANKAN SYARIAH ${ }^{1}$
}

\author{
Frinda Fraktika Devi \\ Mahasiswa Progam Studi S1 Ekonomi Islam - Fakultas ekonomi dan Bisnis - Universitas \\ Airlangga \\ Email: Frinda.fraktika-12@feb.unair.ac.id \\ Noven Suprayogi \\ Departemen Ekonomi Syariah - Fakultas Ekonomi dan Bisnis - Universitas Airlangga \\ Email: noven.suprayogi@feb.unair.ac.id
}

\begin{abstract}
:
This research aims to understand which components from three research variables are cost of loanable fund, overhead cost, and risk factor significantly effected towards financing pricing based on profit sharing in Sharia Banking Industry. This research used two financing aqds are mudharaba and musharaka. The research method was a quantitative method. Statistics tools used Multiple Linear Regression. Samples were used Sharia General Banking and Sharia Unit within Sharia Banking Statistic Reports published by Indonesian Central Bank and Financial Service Authority 2011-2015. The result is three-shaped-price component created financing price neither simultaneously nor partially mudharaba and musharaka. Partial results are cost of loanable fund, overhead cost and risk factor effected significantly towards mudharaba profit sharing rates, and cost of variable significantly to musharaka profit sharing rates.
\end{abstract}

Keywords: cost of loanable funds, overhead cost, risk factor, Pricing of Mudharabah profit sharing,Pricing of Musharaka profit sharing

\section{PENDAHULUAN}

Bank sebagai salah satu lembaga yang bergerak di bidang keuangan dan menempatkan posisi terpenting dalam perekonomian saat ini. Taswan (2010:326) menjelaskan bahwa definisi tentang bank adalah sebuah lembaga yang aktivitasnya menghimpun dana berupa giro, deposito tabungan dan simpanan yang lain dari yang kelebihan dana. (surplus spending unit)kemudian menempatkannya kembali kepada masyarakat yang membutuhkan dana.

Penghimpunan dana ini akan berjalan lancar apabila pihak kelebihan dana maupun pihak kekurangan dana memberikan kepercayaan terhadap bank dalam mengelola dananya.
Aktivitas produktiv di perbankan Islam dinamakan pembiayaan. Secara umum, aktivitas produktif adalah penanaman dana bank Islam baik dalam rupiah maupun valuta asing dalam bentuk pembiayaan, piutang, qardh, surat berharga Islam, penempatan, penyertaan modal, penyertaan modal sementara, kontinjensi pada rekening administratif (Rivai, 2010:681).

(Leon \& Ericson, 2007:3) menjelaskan bahwa kegiatan suatu bank telah terkonsentrasi pada bidang pembiayaan dan pengkreditan baik bank syariah maupun bank konvensional. Kegiatan ini telah memberikan sumbangsih terbesar pada pendapatan bank. pendapatan bank di kalangan Industri Perbankan baik konvensional maupun syariah, nantinya ${ }^{1}$ jurnal ini merupakan bagian dari skripsi frinda fraktika devi. Nim 041211431026 yang diuji 16 februari 2017 
Frinda Fraktika Devi, et al/Jurnal Ekonomi Syariah Teori dan Terapan Vol. 5 No. 1 Januari 2018: 62-77; PENGARUH COST OF LOANABLE FUND, OVERHEAD COST DAN RISK FACTOR TERHADAP PRICING PEMBIAYAAN BERBASIS BAGI HASIL DI INDUSTRI PERBANKAN SYARIAH

akan berupa bunga, margin atau bagi hasil yang akan diberikan kepada nasabah. Berdasarkan kegiatan tersebut, maka pembiayaan merupakan salah satu tugas pokok bank, yaitu pemberian fasilitas penyediaan dan untuk memenuhi kebutuhan pihak-pihak yang merupakan defisit unit (Antonio, 2001:160).

Bank syariah dalam melakukan aktivitasnya hendaknya terhindar dari bunga (riba), melainkan melakukan aktivitas bagi hasil. Disebutkan dalam AlQur'an sebagai sumber utama hukum Islam yaitu surat An-Nisa' (4) ayat 29 :

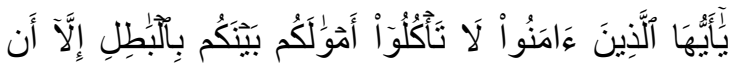

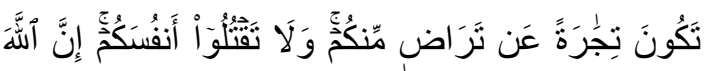

$$
\text { كَانَ بِكُمث رَحِيمّا }
$$

Yā āyyuhālladziina āmanū lā taku'lū amwaalakum baynakum bilbāthili illā an takūna tijāratan 'an taraadin minkum walā taqtulū anfusakum inna allāha kāna bikum rahiimān

"Hai orang-orang yang beriman, janganlah kamu saling memakan harta sesamamu dengan jalan yang batil, kecuali dengan jalan perniagaan yang berlaku dengan suka sama-suka di antara kamu. Dan janganlah kamu membunuh dirimu, sesungguhnya Allah Swt adalah Maha Penyayang kepadamu"(Q.S. AnNisa' 04:29, Departemen agama RI, 2011:83)

Katsir (2015) menjelaskan pada Q.S An-Nisa' ayat 29 bahwa Allah Sw' melarang hambanya yang beriman memakan harta sebagian dari mereka atas sebagian yang lain dengan cara yang batil, yakni melalui usaha yang tidak diakui oleh syariat, seperti dengan cara riba dan judi. Artinya, dalam menjalankan usaha hendaknya dengan cara yang diakui oleh syariat-syariat Islam. Dalam suatu bisnis, hendaknya melakukan aktivitas bagi hasil yang telah sesuai di ajaran Islam dan sesuai dengan yang disepakati.

Menurut febianto dan Kasri (2007:2) dalam Andraeni (2011) pembiayaan berdasarkan bagi hasil yang sering di bahas dalam literatur figh dan umumnya disalurkan perbankan syariah terdiri dari dua jenis, pembiayaan mudharabah dan musyarakah. Mudharabah adalah akad kerjasama usaha antara dua pihak dimana pihak pertama (pemilik dana) menyediakan seluruh dana, sedangkan pihak kedua (pengelola dana) bertindak selaku pengelola, dan keuntungan dibagi di antara mereka sesuai kesepakatan sedangkan kerugian finansial hanya ditanggung oleh pemilik dana. Sementara itu, musyarakah adalah akad kerjasama antara dua pihak atau lebih untuk sesuatu usaha tertentu, dimana masing-masing pihak memberikan kontribusi dana dengan ketentuan bahwa keuntungan dibagi berdasarkan kesepakatan sedangkan kerugian berdasarkan porsi kontribusi dana berupa kas maupun aset non-kas yang diperkenankan oleh syariah (Bank Indonesia, 2013: 5.1 \& 5.5). jadi, akad mudharabah dan musyarakah 
Frinda Fraktika Devi, et al/Jurnal Ekonomi Syariah Teori dan Terapan Vol. 5 No. 1 Januari 2018: 62-77; PENGARUH COST OF LOANABLE FUND, OVERHEAD COST DAN RISK FACTOR TERHADAP PRICING PEMBIAYAAN BERBASIS BAGI HASIL DI INDUSTRI PERBANKAN SYARIAH

adalah salah satu ciri khas di perbankan syariah.

Tabel 1

Proporsi Pembiayaan dan Ekuivalent rate di Industri Perbankan Syariah Tahun 2013-2015

\begin{tabular}{|l|l|l|l|l|l|l|}
\hline \multirow{2}{*}{$\begin{array}{c}\text { Nama } \\
\text { akad }\end{array}$} & \multicolumn{3}{|c|}{2013} & \multicolumn{2}{c|}{2014} & \multicolumn{2}{c|}{2015} \\
\cline { 2 - 7 } & $\begin{array}{l}\text { Proporsi } \\
\text { pembiayaan }\end{array}$ & $\begin{array}{l}\text { Eq. } \\
\text { Rate }\end{array}$ & $\begin{array}{l}\text { Proporsi } \\
\text { pembiayaan }\end{array}$ & $\begin{array}{l}\text { Eq. } \\
\text { Rate }\end{array}$ & $\begin{array}{l}\text { Proporsi } \\
\text { Pembiayaan }\end{array}$ & $\begin{array}{l}\text { Eq. } \\
\text { Rate }\end{array}$ \\
\hline Mudharabah & 13.625 & $14,40 \%$ & 14.354 & $20,69 \%$ & 14.820 & $12,21 \%$ \\
\hline Musyarakah & 39.874 & $12,45 \%$ & 49.387 & $13,61 \%$ & 60.173 & $11,35 \%$ \\
\hline Murabahah & 110.565 & $12,82 \%$ & 117.371 & $15,43 \%$ & 122.111 & $13,36 \%$ \\
\hline Salam & 0 & - & 0 & - & 0 & - \\
\hline Istishna & 582 & $13.36 \%$ & 633 & $12,81 \%$ & 770 & $13,26 \%$ \\
\hline Ijarah & 10.481 & $0,190 \%$ & 11.620 & $9,18 \%$ & 10.631 & $10,51 \%$ \\
\hline
\end{tabular}

Tabel 1 menunjukkan bahwa tingkat proporsi pembiayaan penggunaan akad mudharabah dan musyarakah lebih rendah daripada tingkat proporsi pembiayaan penggunaan akad murabahah. Pada tahun 2013 mudharabah proporsi pembiayaan sebesar 13.625 dengan imbal hasil 12,45\%, sementara penggunaan akad murabahah tingkat proporsi pembiayaan sebesar 110.565 dengan imbal hasil $12,18 \%$. Alasannya, ketika penggunaan akad murabahah lebih unggul daripada penggunaan akad mudharabah dan musyarakah, peristiwa tersebut disebabka oleh penggunaan akad berbasis bagi hasil telah mempunyai tingkat risiko yang tinggi dan tidak pasti yaitu risiko gaga; bayar (kredit macet) sehingga tidak banyak bank menanggung risiko yang berakibat tingkat pendapatan turun (rugi). Maka, munculah penggunaan akad mudharabah dan musyarakah lebih rendah daripada penggunaan akad murabahah, sehingga berpengaruh pada kapasitas nasabah menjadi rendah, serta presepsi masyarakat bahwa meminjam dana di bank syariah biayanya lebih mahal daripada di bank konvensional. Keuntungan suatu usaha/proyek pasti mengalami fluktuasi. Pada tahun 2015, penggunaan akad mengalami penurunan karena imbal hasil (equivalent rate) mengalami penurunan. Penyebabnya adalah kerugian usaha/proyek sehingga equivalent rate lebih rendah daripada proporsi pembiayaanya. Jadi, tingkat imbal hasil yang diberikan sesuai dengan fluktuasi keuntungan usaha/proyek pembiayaan.

$$
\text { Penetapan biaya-biaya yang }
$$
dikeluarkan oleh bank syariah, masih menggunakan komponen pembentuk harga pembiayaan yang sama seperti bank konvensional. Menurut Taswan (2010:325) dalam menentukan komponen pembentuk harga pembiayaan adapun faktor-faktornya sebagai berikut : Cost of Loanable Fund, Overhead Cost, Risk factor, spread dan tax. Jadi, setiap melaksanakan kegiatan yang dilakukan oleh nasabah ada biaya-biaya yang harus dibayarkan oleh nasabah. Biayabiaya tersebut merupakan suatu keuntungan yang didapatkan oleh bank.

Penelitian ini, variabel yang digunakan adalah cost of loanable fund, overhead cost dan risk factor. Alasan menggunakan 
Frinda Fraktika Devi, et al/Jurnal Ekonomi Syariah Teori dan Terapan Vol. 5 No. 1 Januari 2018: 62-77; PENGARUH COST OF LOANABLE FUND, OVERHEAD COST DAN RISK FACTOR TERHADAP PRICING PEMBIAYAAN BERBASIS BAGI HASIL DI INDUSTRI PERBANKAN SYARIAH

ketiga variabel tersebut dikarnakan variabel ini berada pada data Industri Perbankan Syariah. Jika menggunakan kelima variabel makan menggunakan Bank Umum Syariah secara individu.

Equivalent rate merupakan imbal bagi hasil yang diberikan pada nasabah. Penelitian ini, pricing pembiayaan seharusnya menggunakan nisbah bagi hasil, akan tetapi nisbah bagi hasil tersebut akan diproxikan dengan menggunakan data equivalent rate. Alasan dari proxi nisbah menjadi equivalent rate yaitu banyaknya jenis bagi hasil di bank syariah sehingga mempersulit untuk mencari data dan memproses data.

Tabel 2

Suku Bunga Rata-Rata Kredit Bank Konvensional Berdasarkan Jenis Penggunaan Tahun 2013-2015

\begin{tabular}{|c|c|c|c|}
\hline \multirow[t]{2}{*}{ Jenis Penggunaan } & \multicolumn{3}{|c|}{$\begin{array}{c}\text { Suku Bunga Rata-Rata Bank Konvensional } \\
\text { Berdasarkan Jenis Penggunaan (dalam } \\
\text { persen) }\end{array}$} \\
\hline & 2013 & 2014 & 2015 \\
\hline Modal Kerja & $12,14 \%$ & $12,18 \%$ & $12,48 \%$ \\
\hline Investasi & $11,83 \%$ & $12,36 \%$ & $12,12 \%$ \\
\hline Konsumsi & $13,13 \%$ & $13,58 \%$ & $13,88 \%$ \\
\hline
\end{tabular}

Sumber : Statistik Perbankan Indonesia 2013-2015 (www.ojk.gi.id)

Tabel 2 menjelaskan bahwa suku bunga rata-rata kredit bank konvensional berdasarkan jenis penggunaan ada 3 yaitu jenis penggunaan berdasarkan modal kerja, jenis penggunaan berdasarkan investasi, jenis penggunaan berdasarkan konsumsi. Suku bunga ratarata berdasarkan jenis penggunaan investasi merupakan kredit yang menggunakan jangka menengah maupun jangka panjang yang diberikan pada usaha yang bertujuan untuk pembelian mesin. Sedangkan, suku bunga rata-rata berdasarkan jenis penggunaan konsumsi merupakan keperluan konsumsi berupa barang atau jasa dengan cara membeli, menyewa atau dengan cara lainnya (Rivai, 2007:443). Dengan demikian, presentase tabel diatas menunjukkan bahwa suku bunga ratarata bank konvensional mengalami fluktuasi. Sebagai contoh, paa tahun 2013 jenis penggunaan modal kerja sebesar 12,14\%, pada tahun 2014 sebesar 12,81\%, selanjutnya pada tahun 2015 mengalami penurunan sebesar 12,48\%. Artinya, pembiayaan aktiva lancar yang ditujukan pada perusahaan mengalami penurunan pada tahun 2015, sehingga berpengaruh pada suku bunga rata-rata kreditnya. Selanjutnya, jenis penggunaan investasi pada tahun 2013 presentasenya yang paling rendah diantara jenis penggunaan lain yaitu sebesar 11,83\%. Artinya, pada tahun 2013 jenis penggunaan investasi menurun disebabkan oleh risiko kredit bermasalah sehingga berpengaruh pada suku bunga kredit jenis penggunaan investasi. Akan tetapi, pada jenis penggunaan konsumsi presentasenya tiap tahun meningkat. Pada tahun 2013 sebesar 13,13\%, 2014 sebesar 13,58\%, selanjutnya tahun 2015 sebesar 13,88\%. Artinya, pada suku bunga bank konvensional jenis penggunaan konsumsi bisa dipastikan presentasenya stabil. 
Frinda Fraktika Devi, et al/Jurnal Ekonomi Syariah Teori dan Terapan Vol. 5 No. 1 Januari 2018: 62-77; PENGARUH COST OF LOANABLE FUND, OVERHEAD COST DAN RISK FACTOR TERHADAP PRICING PEMBIAYAAN BERBASIS BAGI HASIL DI INDUSTRI PERBANKAN SYARIAH

Tabel 3

Ekuivalent Tingkat Imbalan/Bagi Hasil/Fee/Bonus Pada Pembiayaan Bank Umum Syariah (dalam persen) Pertahun

\begin{tabular}{|c|c|c|c|}
\hline \multirow[t]{2}{*}{ Jenis Akad } & \multicolumn{3}{|c|}{$\begin{array}{c}\text { Ekuivalent Tingkat Imbalan/Bagi Hasil/Fee/Bonus } \\
\text { Pada Pembiayaan Bank Umum Syariah (dalam } \\
\text { persen) Pertahun }\end{array}$} \\
\hline & 2013 & 2014 & 2015 \\
\hline Mudharabah & $14,40 \%$ & $20,68 \%$ & $12,21 \%$ \\
\hline Musyarakah & $12,45 \%$ & $13,61 \%$ & $11,35 \%$ \\
\hline Murabahah & $13,18 \%$ & $15,43 \%$ & $13,36 \%$ \\
\hline Salam & $\cdot$ & - & $\cdot$ \\
\hline Istishna & $13,36 \%$ & $12,81 \%$ & $13,26 \%$ \\
\hline ljarah & $0,19 \%$ & $9,81 \%$ & $10,51 \%$ \\
\hline
\end{tabular}

Sumber : Statistik Perbankan Syariah 2013-2015 (www.ojk.go.id)

Tabel 3 menunjukkan bahwa ekuivalent (imbalan/bagi hasil) pada pembiayaan bank syariah tiap tahun mengalami kenaikan. Tetapi, pada tahun 2015 telah mengalami penurunan. Artinya, setiap usaha/proyek mengalami fluktuasi sehingga berpengaruh pada ekuivalent/ imbalan bagi hasil bank syariah. Sebagai contoh, pada tahun 2013 penggunaan akad musyarakah sebesar $12,45 \%$, pada tahun 2014 13,61\%, selanjutnya tahun 2015 $11,35 \%$. Pada pembiayaan berbasis bagi hasil menggunakan akad murabahah, salam dan istishna, sedangkan pada pembiayaan sewa menggunakan akad ijarah. Dengan demikian, perbandingan akad yang paling menonjol adalah akad mudharabah pada tahun 2013 sebesar $14,40 \%$. Akad mudharabah merupakan akad berbasis bagi hasil, ketika akad tersebut meningkat artinya tingkat keuntungan usah/proyek mengalami peningkatan sehingga berpengaruh pada ekuivalent juga meningkat. Dengan demikian, mudharabah bisa lebih unggul daripada akad yang lain
Kesimpulan dari tabel 2 yang menjelaskan tentang suku bunga ratarata kredit bank konvensional dan tabel 3 menjelaskan tentang ekuivalent imbal/bagi hasil bank syariah, jika keduanya dibandingkan maka sudah tampak bahwa presentase bank konvensional lebih rendah dibandingkan bank konvensional. Artinya, bahwa tingkat pengembalian bank syariah lebih tinggi daripada bank konvensional. Suatu contoh, jenis penggunaan modal kerja bank konvensional tahun 2013 sebesar $12,14 \%$ selanjutnya pada ekuivalent bank syariah pada akad mudharabah tahun 2013 sebesar 14,40\%. Dengan demikian, bisa dipastikan ketika meminjam uang di bank syariah bisa dikatakan lebih mahal daripad di bank konvensional.

Berdasarkan fenomena yang diuraikan diatas, maka penulis tertarik untuk meneliti permasalahan apa yang terjadi tentang penentuan tingkat bagi hasil dengan menggunakan komponen pembentuk harga pembiayaan. Sehingga, menimbulkan besaran harga yang ditetapkan oleh bank syariah lebih tinggi daripada bank konvensional. Dan pada akhirnya, membuat nasabah masih enggan untuk beralih di bank syariah. Dengan penelitian yang berjudul " PENGARUH COST OF LOANABLE FUND, OVERHEAD COST DAN RISK FACTOR TERHADAP PRICING PEMBIAYAAN BERBASIS BAGI HASIL DI INDUSTRI PERBANKAN SYARIAH". 
Frinda Fraktika Devi, et al/Jurnal Ekonomi Syariah Teori dan Terapan Vol. 5 No. 1 Januari 2018: 62-77; PENGARUH COST OF LOANABLE FUND, OVERHEAD COST DAN RISK FACTOR TERHADAP PRICING PEMBIAYAAN BERBASIS BAGI HASIL DI INDUSTRI PERBANKAN SYARIAH

\section{TINJAUAN PUSTAKA}

\section{A. Bank Syariah}

Menurut Rivai dkk, (2007:768) menjelaskan bahwa bank syariah lebih menekankan pada prinsip bagi hasil yang merupakan landasan utama dalam semua operasinya, baik dalam penghimpunan maupun penyaluran dana atau pembiayaan.

\section{B. Pembiayaan Bank Syariah}

Arifin (2009:233) menjelaskan bahwa dalam kegiatan penyaluran dana, bank syariah melakukan investasi dan pembiayaan. Kegiatan investasi berupa penanaman dana atau penyertaan, dan keuntungan yang akan diperoleh bergantung pada kinerja usaha yang menjadi obyek penyertaan tersebut sesuai dengan nisbah bagi hasil yang telah diperjanjikan sebelumnya. kegiatan pembiayaan berupa penyediaan dana guna membiayai kebutuhan nasabah yang layak memperolehnya.

\section{Komponen Pembentuk Harga Pembiayaan}

Menurut Taswan (2010:325) ada 5 komponen dalam menentukan harga pembiayaan antara lain:

1. Cost of Loanable Fund

Cost of Loanable Fund yaitu biaya dana yang dikeluarkan bank setelah diperhitungkan dengan cadangan likuiditas wajib minimum (reserve requirement) yang harus dipelihara oleh bank dan selebihnya disalurkan kepada nasabah berupa penempatan dana, dalam bentuk kredit dan lain-lain (Rivai, 2007:693). Rumus untuk menghitung cost of Loanable Fund adalah :

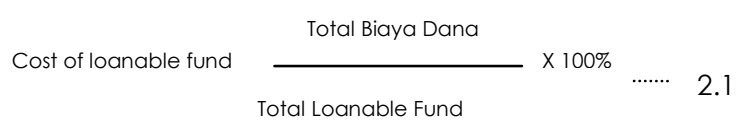

2. Overhead Cost

Overhead cost merupakan biaya yang dikeluarkan oleh bank dalam melaksanakan operasinya (Kasmir, 2010:41). Rumus untuk menghitung Overhead Cost adalah :

$$
\text { Overhead Cost }=\frac{\text { Total Biaya }}{\text { Total Earning Asset }} \times 100 \%
$$

3. Risk Factor

Merupakan salah satu komponen dalam menetapkan base lending rate suatu bank. Kemungkinan risiko yang dihadapi bank dalam penyaluran kredit tidak dapat dihindarkan berupa risiko gagal bayar dari nasabah.

Total Penyisihan Cadangan Penghapusan

Risk Factor $=$

$\mathrm{x} 100 \%$

Kredit yang diklasifikasikan

4. Spread (Laba yang diinginkan)

Merupakan Laba atau keuntungan yang diinginkan oleh bank dan biasanya dalam bentuk presentase (Rivai,2007:695).

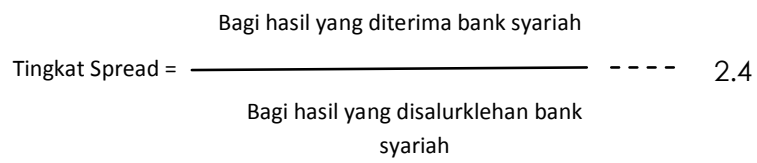

5. Tas rate

Pajak merupakan kewajiban yang dibebankan pemerintah kepada bank yang memberikan fasilitas kredit kepada nasabahnya (Kasmir, 2010:42)

Biaya Pajak = tax rate $x$ spread _..... . $\quad 2.5$ 
Frinda Fraktika Devi, et al/Jurnal Ekonomi Syariah Teori dan Terapan Vol. 5 No. 1 Januari 2018: 62-77; PENGARUH COST OF LOANABLE FUND, OVERHEAD COST DAN RISK FACTOR TERHADAP PRICING PEMBIAYAAN BERBASIS BAGI HASIL DI INDUSTRI PERBANKAN SYARIAH

\section{Model Analisis}

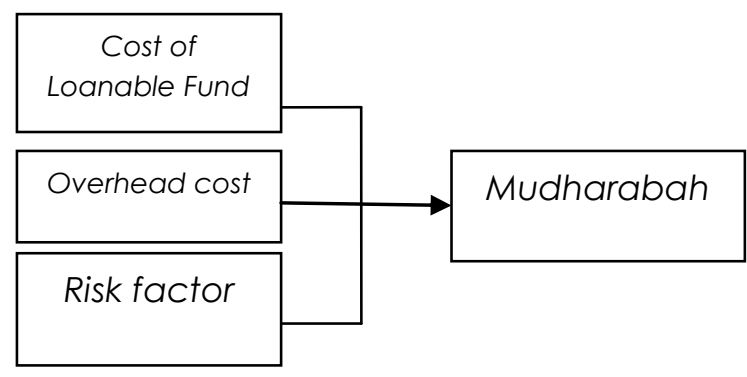

Sumber : Data diolah

Gambar 1

Pengaruh Colf, OHC dan Risk FactorTerhadap Tingkat Bagi Hasil Mudharabah

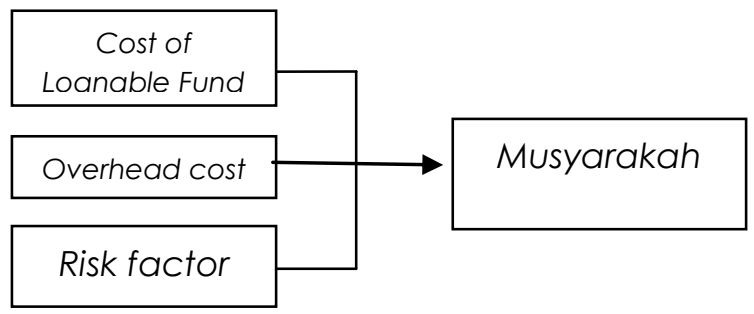

Sumber : Data diolah

\section{Gambar 2}

Pengaruh Colf, OHC dan Risk Factor Terhadap Tingkat Bagi Hasil MUSYARAKAH

\section{METODOLOGI PENELITIAN}

\section{Pendekatan Penelitian}

penelitian kuantitatif merupakan penelitian yang tidak terstruktur dan mengkuantifikasikan data untuk dapat digeneralisasikan.

\section{Identifikasi Variabel}

Variabel bebas (X) dalam penelitian ini adalah Cost of Loanable fund $\left(X_{1}\right)$, Overhead Cost $\left(X_{2}\right)$ dan Risk Factor $\left(\mathrm{X}_{3}\right)$. Variabel terikat $(\mathrm{Y})$ dalam penelitian adalah Tingkat Bagi Hasil Mudharabah $\left(Y_{1}\right)$ dan Musyarakah $\left(Y_{1}\right)$.

\section{Definisi Operasional}

1. Variabel Cost of Loanable Fund (COLF)
Cost of loanable fund adalah biaya dana yang dikeluarkan oleh bank kemudian akan disalurkan pada nasabah dana pihak ketiga meliputi giro, tabungan, dan deposito dengan menggunakan metode biaya rata-rata tertimbang ( Weighted Average Cost of Loanable Fund Methode) setelah disesuaikan oleh giro wajib minimum yang ditentukan oleh Bank Indonesia sebesar 5\%. Berikut adalah rumus COLF :

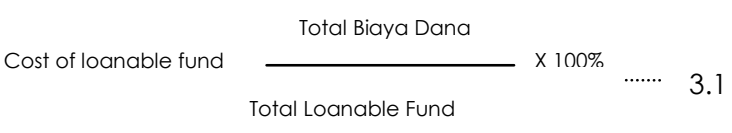

2. Variabel Overhead Cost $(\mathrm{OHC})$

Overhead Cost adalah biaya-biaya yang dikeluarkan oleh bank umum syariah. Biaya ini meliputi biaya gaji, SDM, administrasi dan umum. Sedangkan, total earning asset meliputi penempatan Bank Indonesia, Penempatan Bank Lain, Surat Berharga Dimiliki, Pembiayaan, Aktiva Istishna, dan penyertaan. Berikut adalah rumus $\mathrm{OHC}$ :

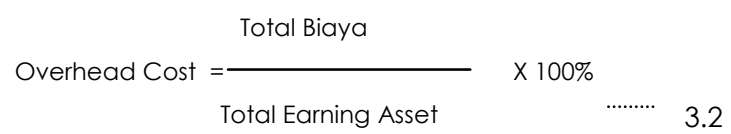

3. Risk Factor

Risk Factor adalah suatu komponen yang dikeluarkan oleh Bank Umum Syariah karena untuk menghindari kredit macet, maka semua bank harus memiliki cadangan aktiva produktif yang diklasifikasikan sehingga nanti akan berpengaruh pada kesehatan bank. Berikut rumus Risk Factor :

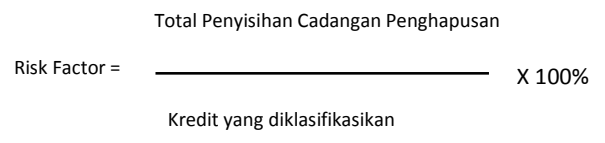


Frinda Fraktika Devi, et al/Jurnal Ekonomi Syariah Teori dan Terapan Vol. 5 No. 1 Januari 2018: 62-77; PENGARUH COST OF LOANABLE FUND, OVERHEAD COST DAN RISK FACTOR TERHADAP PRICING PEMBIAYAAN BERBASIS BAGI HASIL DI INDUSTRI PERBANKAN SYARIAH

4. Variabel Bagi Hasil

Konsep penelitian ini adalah menggunakan pricing pembiayaan berbasis Bagi Hasil yang terdapat pada Industri Perbankan Syariah secara keseluruhan. variabel Bagi Hasil pembiayaan yang berbasis Natural Uncertainty Contract meliputi akad Mudharabah dan Musyarakah.

\section{Jenis dan Sumber Data}

Jenis data yang digunakan dalam penelitian ini adalah data sekunder yang diperoleh dari situs resmi BI (Bank Indonesia) dan situs resmi OJK (Otoritas Jasa Keuangan). Data publikasi ini berasal dari Industri perbankan Syariah di Indonesia secara keseluruhan, yang meliputi komponen harga pembiayaan yaitu cost of loanable fund, overhead cost dan risk factor. Penelitian ini menggunakan dat Time Series dari bulan Januari 2011 sampai dengan bulan Desember 2015.

\section{Prosedur Pengumpulan Data}

a. Populasi

Populasi dalam penelitian ini adalah Industri Perbankan Syariah diantaranya Bank Umum Syariah, Unit Usaha Syariah dan Bank Pengkreditan Rakyat Syariah yang terdapat pada laporan statistik perbankan syariah pada tahun 2011 sampai dengan 2015.

b. Sampel

Menurut Anshori dan Iswati (2009:94) sampel bagian dari jumlah dan karakteristik yang dimiliki oleh populasi.
Sampel yang digunakan seluruh Bank Umum Syariah dan Unit Usaha Syariah yang laporannya tergabung pada statistik perbankan syariah. Bank Pembiayaan Rakyat Syariah tidak disertakan dalam penelitian ini karena terdapat perbedaan tingkat bagi hasil maupun tingkat margin yang ditetapkan oleh Bank Umum Syariah serta Unit Usaha Syariah dengan Bank Pembiayaan Rakyat Syariah. Periode penelitian yang digunakan adalah laporan statistik perbankan syariah dari tahun 2011 sampai dengan 2015. Pengambilan sampel ini dilakukan secara purposive sampling. Adapun kriteria sampel yang digunakan dalam penelitian ini adalah sebagai berikut :

1. Bank syariah yang dapat melakukan fungsi transfer dan kliring.

2. Bank syariah yang terdapat pada Laporan Statistik Perbankan Syariah (SPS) yang diterbitkan oleh Bank Indonesia dan Otoritas Jasa Kevangan.

3. Perbankan Syariah yang terdapat pada Laporan Statistik Perbankan Syariah (SPS) yang telah mempublikasikan laporan bagi hasil equivalent rate dan laporan bulanan periode tahun 2011-2015 secara konsisten melalui website resmi : www.bi.go.id dan www.ojk.go.id.

\section{Teknik Analisis}

Teknik analisis yang digunakan dalam penelitian ini adalah menggunakan regresi linier berganda 
Frinda Fraktika Devi, et al/Jurnal Ekonomi Syariah Teori dan Terapan Vol. 5 No. 1 Januari 2018: 62-77; PENGARUH COST OF LOANABLE FUND, OVERHEAD COST DAN RISK FACTOR TERHADAP PRICING PEMBIAYAAN BERBASIS BAGI HASIL DI INDUSTRI PERBANKAN SYARIAH

dengan data Time Series. Alasan penggunaan regresi linier berganda karena metode ini digunakan untuk mengukur pengaruh variabel bebas terhadap variabel terikat. Analisis ini dilakukan menggunakan program SPSS 21. Sebelum dilakukan uji regresi linier berganda menggunakan program SPSS 21, data diolah menggunakan program Microsoft Excel 2010. Langkah pertama dalam teknik analisis ini adalah Uji asumsi klasik. Ada 4 uji yang harus dilakukan sebelum melakukan uji regresi, yaitu : Uji Normalitas, Uji Multikolinearitas, Uji Heteroskedastisitas, Uji Autokolerasi. Selanjutnya, akan dilanjutkan pengujian regresi yaitu uji $F$ (simultan) dan uji $\dagger$ (parsial). Terakhir, koefisien determinasi yang berguna untuk mengukur besarnya sumbangan variabel independen secara keseluruhan terhadap variabel dependen. Dimana bila semakin tinggi $\left(0,7>R^{2}>1\right)$ nilai R2 suatu regresi tersebut akan semakin baik, yang berarti bahwa keseluruhan variabel regresi tersebut akan semakin baik, artinya secara keseluruhan variabel bebas secara bersama-sama mampu menerangkan variabel independen (Sarjono, 2011:112).

\section{HASIL DAN PEMBAHASAN}

1. Uji Normalitas

Untuk menganalisis asumsi normalitas yaitu melihat grafik normal pola menunjukkan penyebaran titik-titik di sekitar diagonal, dan mengikuti arah garis diagonal. Berikut adalah hasil uji normalitas indikator variabel independen dengan tiap variabel dependen dapat dilihat dalam gambar 3 dan 4 .

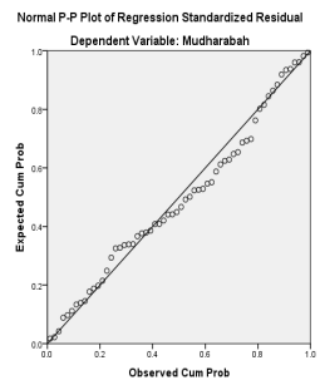

Gambar 3

Hasil uji Normalitas Cost of Loanable Fund, Overhead Cost, dan Risk Factor Terhadap Pricing Berbasis Bagi hasil Mudharabah Sumber : Data SPSS, diolah.

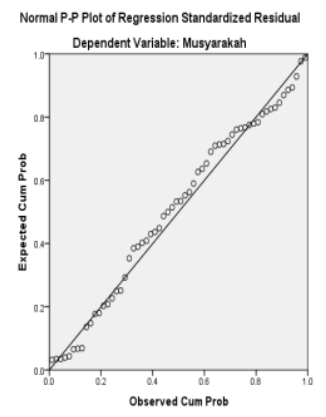

Gambar 3

Hasil uji Normalitas Cost of Loanable Fund, Overhead Cost, dan Risk Factor Terhadap

Pricing Berbasis Bagi hasil Musyarakah Sumber : Data SPSS, diolah.

2. Uji Mulitikolinearitas

Untuk mendeteksi ada tidaknya problem multikolinearitas pada model regresi dengan melihat nilai Tolerance dan VIF (variance inflation factor). Nilai yang direkomendasikan untuk menunjukkan tidak adanya problem multikolinearitas adalah nilai tolerance harus $>0,10$ dan nilai VIF $<10$. Hal ini agar tidak terjadi 
Frinda Fraktika Devi, et al/Jurnal Ekonomi Syariah Teori dan Terapan Vol. 5 No. 1 Januari 2018:

62-77; PENGARUH COST OF LOANABLE FUND, OVERHEAD COST DAN RISK FACTOR TERHADAP PRICING PEMBIAYAAN BERBASIS BAGI HASIL DI INDUSTRI PERBANKAN SYARIAH

gejala multikolinearitas dalam hubungan antar variabel dalam penelitian ini.

Tabel 1

Hasil Uji Multikolinearitas Cost of loanable fund, Overhead Cost, dan Risk Factor Terhadap Pricing Berbasis Bagi Hasil

Mudharabah

\begin{tabular}{|c|c|c|c|}
\hline $\begin{array}{c}\text { Variabel } \\
\text { bebas }\end{array}$ & Tolerance & Nilai VIF & Keterangan \\
\hline $\begin{array}{c}\text { Cost of } \\
\text { loanable fund }\end{array}$ & 0.402 & 2.485 & $\begin{array}{c}\text { Tidak Terjadi } \\
\text { Multikolinearitas }\end{array}$ \\
\hline $\begin{array}{c}\text { Overhead } \\
\text { Cost }\end{array}$ & 0.931 & 1.074 & $\begin{array}{c}\text { Tidak terjadi } \\
\text { Multikolinearitas }\end{array}$ \\
\hline Risk Factor & 0.413 & 2.424 & $\begin{array}{c}\text { Tidak Terjadi } \\
\text { Multikolinearitas }\end{array}$ \\
\hline
\end{tabular}

Sumber : Data SPSS. diolah

Tabel 2

Hasil Uji Multikolinearitas Cost of loanable fund, Overhead Cost, dan Risk Factor Terhadap Pricing Berbasis Bagi Hasil

Musyarakah

\begin{tabular}{|c|c|c|c|}
\hline $\begin{array}{c}\text { Variabel } \\
\text { bebas }\end{array}$ & Tolerance & Nilai VIF & Keterangan \\
\hline $\begin{array}{c}\text { Cost of } \\
\text { loanable fund }\end{array}$ & 0.402 & 2.485 & $\begin{array}{c}\text { Tidak Terjadi } \\
\text { Multikolinearitas }\end{array}$ \\
\hline $\begin{array}{c}\text { Overhead } \\
\text { Cost }\end{array}$ & 0.931 & 1.074 & $\begin{array}{c}\text { Tidak terjadi } \\
\text { Multikolinearitas }\end{array}$ \\
\hline Risk Factor & 0.413 & 2.424 & $\begin{array}{c}\text { Tidak Terjadi } \\
\text { Multikolinearitas }\end{array}$ \\
\hline
\end{tabular}

Sumber : Data SPSS. diolah

3. Uji Heteroskedastisitas

Pengujian gejala heteroskedasitas diketahui dengan melihat apakah titik-titik memiliki pola tertentu yang teratur seperti bergelombang melebar kemudian menyempit, jika terjadi maka mengindikasikan terdapat gejala tersebut. Jikat tidak terdapat pola tertentu yang jelas, serta titik-titik menyebar di atas dan di bawah angka 0 pada sumbu $Y$ maka mengindikasikan tidak terjadi heteroskedastisitas.

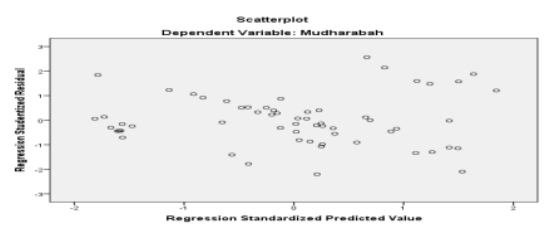

Gambar 6

Hasil Uji heteroskedastisitas cost of loanable fund, overhead cost dan risk factor terhadap pricing berbasis bagi hasil Mudharabah

Sumber : Data SPSS, diolah

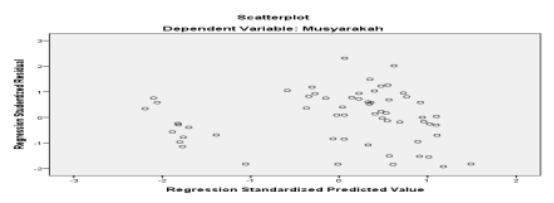

Gambar 7

Hasil Uji heteroskedastisitas cost of loanable fund, overhead cost dan risk factor terhadap pricing berbasis bagi hasil Musyarakah

Sumber : Data SPSS, diolah

4. Uji Autokorelasi

Autokorelasi adalah suatu keadaan dimana variabel-variabel gangguan pada periode tertentu berkorelasi dengan variabel gangguan pada periode lain. Cara untuk mendeteksi autokorelasi adalah dengan melihat nilai DurbinWatson. Jika nilai DW diantara -2 dan +2 atau $-2 \leq \mathrm{DW} \leq+2$ maka tidak terjadi autokorelasi.

Tabel 3

Uji Heteroskedastisitas cost of loanable fund, overhead cost, dan risk factor terhadap pricing berbasis bagi hasil

\begin{tabular}{|l|r|r|r|r|r|}
\hline $\begin{array}{l}\text { Mode } \\
1\end{array}$ & $R$ & $\begin{array}{c}\mathrm{R} \\
\text { Square }\end{array}$ & $\begin{array}{c}\text { Adjusted R } \\
\text { Square }\end{array}$ & $\begin{array}{c}\text { Std. Error of } \\
\text { the Estimate }\end{array}$ & $\begin{array}{r}\text { Durbin- } \\
\text { Watson }\end{array}$ \\
\hline 1 & $.683^{\mathrm{a}}$ & .467 & .438 & 1.95454 & .755 \\
\hline
\end{tabular}

Sumber :Data SPSS, diolah

Tabel 3

Uji Heteroskedastisitas cost of loanable fund, overhead cost, dan risk factor terhadap pricing berbasis bagi hasil

musyarakah

\begin{tabular}{|l|c|c|c|c|c|}
\hline Model & $R$ & $R$ & Adjusted $R$ & Std. Error of & Durbin- \\
& & Square & Square & the Estimate & Watson \\
\hline
\end{tabular}


Frinda Fraktika Devi, et al/Jurnal Ekonomi Syariah Teori dan Terapan Vol. 5 No. 1 Januari 2018: 62-77; PENGARUH COST OF LOANABLE FUND, OVERHEAD COST DAN RISK FACTOR TERHADAP PRICING PEMBIAYAAN BERBASIS BAGI HASIL DI INDUSTRI PERBANKAN SYARIAH

\begin{tabular}{|l|l|l|l|l|l|}
\hline 1 & .6970 & .486 & .458 & .69559 & 1.181 \\
\hline
\end{tabular}

Sumber :Data SPSS, diolah

Pengujian Hipotesis Pengaruh cost of loanable fund, overhead cost dan risk factor terhadap pricing pembiayaan berbasis bagi hasil mudharabah

hasil uji statistik pada model regresi pertama variabel independen diantaranya cost of loanable fund $\left(x_{1}\right)$, overhead cost $\left(x_{2}\right)$ dan risk factor $\left(x_{3}\right)$ terhadap variabel dependen tingkat bagi hasil mudharabah $\left(Y_{1}\right)$ adalah sebagai berikut :

Tabel 4

Pengaruh Cost of Loanable Fund, Overhead Cost dan Risk Factor terhadap Tingkat bagi hasil mudharabah

\begin{tabular}{|l|l|l|l|}
\hline Variabel & $\begin{array}{l}\text { Koefisien } \\
\text { Regresi }\end{array}$ & T & signfikansi \\
\hline (Constan) & 10.254 & 5.506 & 0.000 \\
\hline $\begin{array}{l}\text { Cost of } \\
\text { Loanable fund }\end{array}$ & -1.495 & -5.572 & 0.000 \\
\hline $\begin{array}{l}\text { Overhead } \\
\text { cost }\end{array}$ & 0.328 & 3.283 & 0.002 \\
\hline Risk factor & 3.822 & 5.051 & 0.000 \\
\hline $\begin{array}{l}\text { Koefisien } \\
\text { korelasi (R) }\end{array}$ & \multicolumn{3}{|c|}{0.683} \\
\hline $\begin{array}{l}\text { Koefisien } \\
\text { determinasi }\end{array}$ & 0.467 \\
\hline Uji f 16.336 \\
\hline Signifikansi \\
$\begin{array}{l}\text { Sumber: hasil pengolahan data(lampiran) } \\
\text { Tabel di hasil regresi diatas untuk model }\end{array}$ \\
analisis yang pertama menunjukkan:
\end{tabular}

1. Hasil uji $F$ (simultan) menunjukkan bahwa pengaruh cost of loanable fund, overhead cost, dan risk factor terhadap tingkat bagi hasil mudharabah sebesar 16.336 dengan tingkat signifikansi 0.000 . nilai signifikansi ini lebih kecil dari 0,05 sehingga dapat disimpulkan bahwa variabel cost of loanable fund, overhead cost dan risk factor secara bersama berpengaruh sangat signifikant terhadap tingkat bagi hasil mudharabah (menerima $\mathrm{H}_{1}$ ).

2. Hasil pengujian parsial atau uji $†$ pada tabel menunjukkan bahwa cost of loanable fund memiliki signifikansi sebesar 0.000 , overhead cost memiliki nilai signifikansi sebesar 0.002 , dan risk factor memiliki signifikansi sebesar 0.000. berdasarkan hasil uji diatas bahwa semua variabel harga diantaranya cost of loanable funf, overhead cost, dan risk factor nilainya lebih kecil dari 0,05. Jadi bisa disimpulkan bahwa semua variabel secara parsial berpengaruh signifikant terhadap tingkat bagi hasil mudharabah (menerima $\mathrm{H}_{2}$ ).

3. Hasil perhitungan koefisien determinasi atau $R^{2}$ menunjukkan sebesar 0.467, hal ini menunjukkan bahwa variabel cost of loanable fund, overhead cost, dan risk factor dapat menjelaskan variabel tingkat bagi hasil mudharabah sebesar $\quad 46,7 \%$. Sedangkan 53,3\% dijelaskan oleh variabel lain yang tidak diteliti dalam penelitian ini.

Pengujian Hipotesis Pengaruh cost of loanable fund, overhead cost dan risk factor terhadap pricing pembiayaan berbasis bagi hasil musyarakah

Hasil uji statistik pada model regresi kedua yaitu menggunakan variabel independen diantaranya cost of loanable fund $\left(x_{1}\right)$, overhead cost $\left(x_{2}\right)$ dan risk factor $\left(x_{3}\right)$ terhadap variabel dependen tingkah 
Frinda Fraktika Devi, et al/Jurnal Ekonomi Syariah Teori dan Terapan Vol. 5 No. 1 Januari 2018: 62-77; PENGARUH COST OF LOANABLE FUND, OVERHEAD COST DAN RISK FACTOR TERHADAP PRICING PEMBIAYAAN BERBASIS BAGI HASIL DI INDUSTRI PERBANKAN SYARIAH

bagi hasil musyarakah (Y1) adalah sebagai berikut :

Tabel 5

Pengaruh Cost of Loanable Fund, Overhead Cost dan Risk Factor terhadap Tingkat bagi hasil musyarakah

\begin{tabular}{|l|l|l|l|}
\hline Variabel & $\begin{array}{l}\text { Koefisien } \\
\text { Regresi }\end{array}$ & $\mathrm{T}$ & Signfikansi \\
\hline (Constan) & 15.152 & 22.862 & 0.000 \\
\hline $\begin{array}{l}\text { Cost of } \\
\text { Loanable fund }\end{array}$ & -0.401 & -4.199 & 0.000 \\
\hline $\begin{array}{l}\text { Overhead } \\
\text { cost }\end{array}$ & 0.069 & 1.946 & 0.057 \\
\hline Risk factor & 0.032 & 0.117 & 0.907 \\
\hline $\begin{array}{l}\text { Koefisien } \\
\text { korelasi (R) }\end{array}$ & \multicolumn{3}{|c|}{$0.697 \mathrm{a}$} \\
\hline $\begin{array}{l}\text { Koefisien } \\
\text { determinasi }\end{array}$ & \multicolumn{3}{|c|}{0.486} \\
\hline Uji f & \multicolumn{3}{|c|}{0.630} \\
\hline Signifikansi & \multicolumn{3}{|c|}{$000^{\mathrm{b}}$} \\
\hline
\end{tabular}

Tabel hasil regresi diatas untuk model analisis yang kedua menunjukkan :

1. Hasil uji $F$ (simultan) menunjukkan bahwa pengaruh cost of loanable fund, overhead cost dan risk factor terhadap tingkat bagi hasil musyarakah sebesar 17.630 dengan tingkat signifikansi 0.000 . nilai signifikansi ini lebih kecil dari 0,5 sehingga dapat disimpulkan bahwa variabel cost of loanable fund, overhead cost dan risk factor secara bersama berpengaruh secara signifikant terhadap tingkat bagi hasil musyarakah (Menerima $\mathrm{H}_{3}$ ).

2. Hasil pengujian parsial atau uji t pada tabel menunjukkan bahwa cost of loanable fund memiliki nilai signifikansi sebesar 0.000, selanjutnya variabel overhead cost memiliki probabilitas sebesar 0.057, dan risk factor memiliki probabilitas sebesar 0.907. variabel yang memiliki nilai signifikansi adalah variabel cost of loanable fund. Sehingga bisa disimpulkan bahwa variabel cost of loanable fund secara parsial berpengaruh signifikant terhadap tingkat bagi hasil musyarakah (menerima $\mathrm{H}_{4}$ ).

3. Hasil perhitungan koefisien determinasi atau R2 menunjukkan sebesar 0.486 , hal ini menunjukkan bahwa variabel cost of loanable fund, overhead cost, dan risk factor dapat menjelaskan variabel tingkat bagi hasil musyarakah sebesar 48,6\%, sedangkan 51,4\% dijelaskan oleh variabel lain yang tidak diteliti dalam penelitian ini.

\section{Pembahasan}

Pada penelitian ini, bertujuan untuk mengetahui alasan dari tingginya meminjam dana di bank syariah dari pada di bank konvensional. Akad yang digunakan dalam penelitian ini menggunakan akad bagi hasil yaitu mudharabah dan musyarakah.

Pada umumnya, bagi hasil pembiayaan merupakan akad yang tidak pasti dalam pengembalian imbal hasilnya. Akad yang mempunyai tingkat risiko yang tinggi sehingga tidak banyak bank mau menanggung risiko. Akan tetapi, akad bagi hasil merupakan suatu instrumen bank yang harus di unggulkan lagi.

Bagi hasil pembiayaan yang ditetapkan oleh bank syariah itu lebih tinggi dari pada bank konvensional. Artinya, bahwa meminjam dana di bank syariah biayanya lebih tinggi dari pada di bank konvensional. Bank syariah menetapkan bagi hasil lebih tinggi di awal 
Frinda Fraktika Devi, et al/Jurnal Ekonomi Syariah Teori dan Terapan Vol. 5 No. 1 Januari 2018: 62-77; PENGARUH COST OF LOANABLE FUND, OVERHEAD COST DAN RISK FACTOR TERHADAP PRICING PEMBIAYAAN BERBASIS BAGI HASIL DI INDUSTRI PERBANKAN SYARIAH

akad untuk menghindari kerugian riil di kemudian hari. Maka, bagi hasil otomatis lebih tinggi dari pada bank konvensional.

$$
\text { Dalam menetapkan pricing }
$$

berbasis bagi hasil, bank syariah memperhitungkan komponen harga pembiayaan. Komponen harga pembiayaan yang digunakan oleh bank syariah masih sama dengan bank konvensional diantaranya: cost of loanable fund, overhead cost, risk factor, spread dan tax (Taswan, 2010:325). Dalam penelitian ini, komponen yang digunakan adalah cost of loanable fund, overhead cost dan risk factor.

Pengaruh cost of loanable fund, overhead cost, dan risk factor simultan terhadap pricing pembiayaan berbasis bagi hasil mudharabah

Berdasarkan model regresi yang telah dilakukan pada variabel dependen pricing pembiayaan berbasis bagi hasil mudharabah adalah cost of loanable fund, overhead cost dan risk factor secara simultan berpengaruh signifikant terhadap bagi hasil baik mudharabah. hal ini sejalan dengan penelitian yang dikemukakan oleh Hayati (2015) dan Qomariah (2015) bahwa cost of loanable fund, overhead cost dan risk factor adalah komponen pembentuk harga bagi hasil/margin pembiayaan. Hal ini juga dikemukakan oleh Taswan dalam bukunya yang berjudul " Manajemen Perbankan" bahwa komponen pembentuk harga pembiayaan berpengaruh pada bagi hasil/margin. Karena pada dasarnya besarnya bagi hasil didapatkan dari hasil penjumlahan komponen pembentuk harga pembiayaan diantaranya cost of loanable fund, overhead cost risk factor, spread dan tax. Sehingga apabila terjadi perubahan dari komponen-komponen tersebut maka bagi hasil yang ditetapkan juga akan mengalami perubahan.

Pengaruh cost of loanable fund, overhead cost, dan risk factor parsial terhadap pricing pembiayaan berbasis bagi hasil mudharabah

Berdasarkan regresi yang dilakukan pada variabel dependen pricing pembiayaan berbasis bagi hasil mudharabah secara parsial menyatakan bahwa ketiga variabel tersebut diantaranya cost of loanable fund, overhead cost, dan risk factor berpengaruh secara signifikant terhadap pricing pembiayaan berbasis bagi hasil mudharabah. Hal ini tidak sejalan dengan penelitian sebelumnya yang dikemukakan oleh Hayati (2015) yaitu "cost of loanable fund, overhead cost dan risk factor secara parsial berpengaruh terhadap tingkat margin pembiayaan murabahah". Akan tetapi, walaupun hasil penelitian menyatakan bahwa ketiga variabel berpengaruh signifikant terhadap bagi hasil pembiayaan mudharabah, cost of loanable fund mengalami negatif signifikant. Artinya, ketika bagi hasil pembiaayaan naik maka biaya dana turun. Biaya dana turun disebabkan oleh 
Frinda Fraktika Devi, et al/Jurnal Ekonomi Syariah Teori dan Terapan Vol. 5 No. 1 Januari 2018: 62-77; PENGARUH COST OF LOANABLE FUND, OVERHEAD COST DAN RISK FACTOR TERHADAP PRICING PEMBIAYAAN BERBASIS BAGI HASIL DI INDUSTRI PERBANKAN SYARIAH

dana murah yang tinggi yaitu berasal dari dana tabungan. Pada bank syariah, dana dibagi menjadi dua yaitu dana murah dan dana mahal. Ketika biaya dana turun maka dana mahal yang berasal deposito turun jadi biaya dana yang dibagikan ke nasabah juga turun dikarnakan deposito adalah dana mahal dan sangat berpengaruh pada equivalent ratenya.

Pengaruh cost of loanable fund, overhead cost, dan risk factor simultan terhadap pricing pembiayaan berbasis bagi hasil musyarakah

Musyarakah merupakan akad kerjasama di antara para pemilik modal yang mencampurkan modal mereka untuk tujuan mencari keuntungan. Berdasarkan model regresi yang dilakukan variabel dependen pricing berbasis bagi hasil musyarakah secara simultan menyatakan bahwa ketiga variabel tersebut diantaranya cost of loanable fund, overhead cost dan risk factor berpengaruh signifikan terhadap pricing berbasis bagi hasil musyarakah. hal ini sejalan dengan bukunya Ikatan Bankir Indonesia yang berjudul "Mengelola Bisnis Pembiayaan Bank Syariah" yang menyatakan bahwa komponen harga pembiayaan berpengaruh pada penentuan bagi hasil di bank syariah.

Pengaruh cost of loanable fund, overhead cost, dan risk factor parsial terhadap pricing pembiayaan berbasis bagi hasil musyarakah
Berdasarkan model regresi yang dilakukan pada variabel dependen tingkat bagi hasil musyarakah secara parsial menyatakan bahwa ketiga variabel tersebut diantaranya cost of loanable fund, overhead cost dan risk factor yang berpengaruh signifikant hanya cost of loanable fund saja. Keadaan cost of loanable fund sama seperti mudharabah yaitu mengalami negatif signifikant. Perbedaan dari mudharabahdan musyarakah adalah terletak di bagian kontribusi dananya. Penggunaan akad mudharabah merupakan akad kerjasama usaha antara kedua belah pihak, dimana pihak pertama (pemilik dana) yang bertujuan menyediakan dana sedangkan pihak kedua (pengelola dana) bertindak sebagai mengelola dana dan keuntungan dibagi diantara mereka sesuai dengan kesepakatan. Sedangkan, musyarakah adalah akad kerjasama antara dua pihak atau lebih, dimana masing-masing pihak memberikan kontribusi dana dan segala keuntungan berdasarkan masing-masing kontribusi dana. Jadi penggunaan akad mudharabah, bank tidak ikut campur dalam usaha tersebut, bank hanya menyediakan dana saja, segala kerugian juga ditanggung oleh pemilik dana, sehingga hal ini sangat berpengaruh pada biaya diluar dana bank maupun kredit macet. sedangkan, penggunaan akad musyarakah masing-masing kontribusi dana ikut campur pada usaha 
Frinda Fraktika Devi, et al/Jurnal Ekonomi Syariah Teori dan Terapan Vol. 5 No. 1 Januari 2018: 62-77; PENGARUH COST OF LOANABLE FUND, OVERHEAD COST DAN RISK FACTOR TERHADAP PRICING PEMBIAYAAN BERBASIS BAGI HASIL DI INDUSTRI PERBANKAN SYARIAH

tersebut, segala keuntungan juga berdasarkan kontribusi dana tersebut, segala kerugian juga berdasaekan kontribusi dana tersebur, sehingga apapun yang terjadi musyarakah bisa diartikan saling bekerja sama, berkongsi, berserikat dan bermitra. Berikut adalah karakterisistik musyarakah diantaranya (Wiroso, 201 1:396):

a. Pernyataan ijab dan kabul harus dinyatakan oleh para pihak

b. Penawaran dan penerimaan harus secara eksplisit menunjukkan tujuan kontrak (akad)

c. Akad dituangkan secara tertulis, melalui korespondensi

d. Setiap mitra harus menyediakan dana dan pekerjaan, dan setiap mitra melaksanakan kerja sebagai wakil

e. Setiap mitra harus memiliki hak untuk mengatur menyediakan dana dan pekerjaan dan setiap mitra melaksanakan kerja sebagai wakil

f. Kerugian harus dibagi antara para mitra secara proposional menurut saham masing-masing dalam modal

g. Biaya operasional dibebankan pada modal bersama.

\section{v. SIMPULAN}

Berdasarkan data dan hasil yang telah dilakukan maka dapat diambil kesimpulan sebagai berikut :

1. Hasil dari uji simultan pada model regresi yang menggunakan variabel dependen tingkat bagi hasil mudharabah adalah variabel cost of loanable fund, overhead cost, dan risk factor secara simultan berpengaruh secara signifikant terhadap tingkat bagi hasil mudharabah.

2. Hasil dari uji parsial untuk model yang menggunakan variabel dependen tingkat bagi hasil mudharabah adalah variabel cost of loanable fund, overhead cost, dan risk factor secara parsial berpengaruh signifikant terhadap variabel tingkat bagi hasil mudharabah.

3. Hasil dari uji simultan pada model regresi yang menggunakan variabel dependen tingkat bagi hasil musyarakah adalah variabel cost of loanable fund, overhead cost, dan risk factor secara simultan berpengaruh signifikant terhadap tingkat bagi hasil musyarakah

4. Hasil dari uji parsial untuk model yang menggunakan variabel dependen tingkat bagi hasil musyarakah adalah variabel cost of loanable fund secara parsial berpengaruh signifikant terhadap bagi hasil musyarakah.

\section{DAFTAR PUSTAKA}

Andraeni, Ditta. 2011. Analisis Pengaruh Dana Pihak Ketiga, Tingkat Bagi Hasil, Dan Non Performing Financing Terhadap Volume Pembiayaan Berbasis Bagi Hasil Pada Perbankan Syariah Di Indonesia. Banda aceh Fakultas Ekonomi Universitas Syiah Kuala. (Online).

http://multiparadigma.lecture.ub.a c.id/files/2014/10SNA-14-047.pdf Diakses, tanggal 28 desember 2016 pukul 17.41 
Frinda Fraktika Devi, et al/Jurnal Ekonomi Syariah Teori dan Terapan Vol. 5 No. 1 Januari 2018: 62-77; PENGARUH COST OF LOANABLE FUND, OVERHEAD COST DAN RISK FACTOR TERHADAP PRICING PEMBIAYAAN BERBASIS BAGI HASIL DI INDUSTRI PERBANKAN SYARIAH

Arifin, Zainul. 2009. Dasar - Dasar Manajemen Bank Syariah. Jakarta: azkia Publisher.

Departemen Agama RI. 2011. AlQuran Tajwid \& Terjemah. Bandung : $\mathrm{C} v$ Penerbit Diponegoro

Hayati, Riris Rizky. 2015. Pengaruh Cost Of Loanable Fund, Overhead Cost, dan Risk Factor terhadap tingkat margin pembiayaan berbasis Natural Uncertainty Contract di Industri Perbankan Syariah. Skripsi tidak diterbitkan. Surabaya Fakultas Ekonomi dan Bisnis Universitas Airlangga

Indonesia, Bank. 2013. Pedoman Akuntansi Perbank Syariah Indonesia. Lampiran Surat Edaran Bank Indonesia Nomor 15/26/Dpbs Tanggal 10 Juli 2013 Perihal Pelakasanaan Pedoman Akuntansi Perbankan Syariah Indonesia. Bank Indonesia

Indonesia, Ikatan Bankir. 2015. Mengelola Bisnis Pembiayaan Bank Syariah, modul seritifkasi pembiayaan syariah I. Jakarta : PT Gramedia Pustaka Utama

Kasmir. 2010. Manajemen Perbankan. Jakarta : PT RajaGrafindo Persada Leon, Boy dan Sonny Ericson. 2007. Manajemen Aktiva Pasiva Bank Non Devisa. Jakarta; PT. Grasindo

Qomariyah, Nurul. 2015. Metode Penentapan Pricing Kredit Pemilikan Rumah Syariah (Studi Kasus : Bank Jatim Syariah ). Skripsi tidak diterbitkan. Surabaya Fakultas Ekonomi dan Bisnis Universitas Airlangga

Rivai, Veithzal dkk.2007a. Islamic Financial Management. Jakarta : RajaGrafindo persada

Sarjono, Haryadi dan Winda Julianita. 2011. SPSS VS LISREL, Sebuah Pengantar, Aplikasi Untuk Riset. Jakarta : Salemba empat

Taswan.2010.Manajemen Perbankan. Konsep, Teknik dan Aplikasi Edisi 2. Yogyakarta : UPP STIM YKPN

Wiroso. 2011. Akuntansi Transaksi Syariah. Jakarta: Ikatan Akuntan Indonesia www.bi.go.id diakses pada tanggal 11 januari 2017 pukul 17.00

www.ojk.id diakses pada tanggal 11 januari 2017 pukul 17.00

http://www.ibnukatsironline.com/2015/05/ tafsir-surat-nisa-ayat-29-31_2.html Idiakses tanggal 1 januari 2017 pukul 16.00)

http://tafsira.com/26-Asy-Syu'ara'/ayat183\#tafsir-quraish-shihab (diakses tanggal 2 januari 2017 pukul 17.00) 